\title{
Purification and Characterisation of a Fibrinolytic Enzyme from Rhizopus microsporus var. tuberosus
}

\author{
Shuli Zhang, Yingdong Wang, Nan Zhang, Zhe Sun, Yan Shi, Xingnan Cao and \\ Haikuan Wang*
}

Key Laboratory of Industrial Fermentation Microbiology, College of Biotechnology, Tianjin University of Science and Technology, Ministry of Education, Tianjin, PR China

Received: August 25, 2014

Accepted: March 9, 2015

\begin{abstract}
Summary
Extracellular fibrinolytic enzyme from Rhizopus microsporus var. tuberosus was purified and characterised. The microorganism was isolated in a distillery from daqu, a fermentative agent used in the production of Chinese liquor and vinegar at different temperatures. The fibrinolytic enzyme was partially purified by ammonium sulphate precipitation, dialysis, DEAE Sepharose ${ }^{\circledR}$ Fast Flow ion exchange chromatography and Sephadex G-75 gel filtration chromatography. The molecular mass of the fibrinolytic enzyme was estimated to be $24.5 \mathrm{kDa}$ by SDS-PAGE. The purified enzyme showed optimal activity at $\mathrm{pH}=7.0$ and 37 ${ }^{\circ} \mathrm{C}$ by fibrin plate method. It showed stronger resistance to the inhibition by trypsin and was stable at $37^{\circ} \mathrm{C}$ retaining $96.1 \%$ residual activity after $4 \mathrm{~h}$ of incubation. The fibrinolytic activity of the enzyme was enhanced by $\mathrm{Na}^{+}, \mathrm{Ca}^{2+}, \mathrm{Mg}^{2+}$ and $\mathrm{Mn}^{2+}$. Conversely, $\mathrm{Zn}^{2+}$ and $\mathrm{Cu}^{2+}$ partly inhibited enzymatic activity. Using fibrin plate method, we found that the enzyme not only degrades fibrin directly, but also activates plasminogen into plasmin to degrade fibrin. The results indicate that the pure enzyme has a potential in dissolving blood clot, and the possibility for application in the treatment of thrombosis.
\end{abstract}

Key words: Rhizopus microsporus var. tuberosus, fibrinolytic enzyme, purification, characterisation

\section{Introduction}

Cardiovascular diseases, such as acute myocardial infarction, ischaemic heart disease and high blood pressure, are the leading causes of death in the world (1). Thrombin-mediated fibrinogen conversion to fibrin and fibrin monomer cross-linking result in the formation of a clot. Thrombosis occurs when the clots are not lysed. Plasmin, which is generated from plasminogen by activators, such as tissue plasminogen activator (t-PA) and urokinase, hydrolyses insoluble fibrin fibre into fibrin degradation products. A variety of plasminogen activators have been widely studied and used as thrombolytic agents. However, these agents are very expensive and have some side effects (2).
Over the last decade, the search for other fibrinolytic enzymes from various sources has been under way. Several potential thrombolytic agents have been discovered from animals, e.g. vampire bat saliva (3), earthworm (4) and snake venoms (5), whose effects were confirmed in clinical trials (6). In addition, the fibrinolytic enzymes have also been isolated and characterised from fermented food products including Korean chungkookjang (7), Japanese natto (8) and Chinese douchi (9). These enzymes can convert plasminogen to plasmin.

Our study reports for the first time the purification and characterisation of the fibrinolytic enzyme from Rhizopus microsporus var. tuberosus isolated in a distillery from daqu, a fermentative agent produced at a medium temperature. 


\section{Materials and Methods}

\section{Materials}

Thrombin, fibrinogen from bovine plasma, urokinase and Sepharose were purchased from Sigma-Aldrich (St. Louis, MO, USA). Trypsin was purchased from Biotech (Shanghai, China). DEAE-Sepharose Fast Flow and Sephadex G-75 were purchased from GE Healthcare (Hartford, CT, USA). All other reagents were of analytical grade.

\section{Strain and culture conditions}

The conidia of Rhizopus microsporus var. tuberosus, kept at $-80{ }^{\circ} \mathrm{C}$ in $20 \%$ (by volume) glycerol, were used to inoculate PDA agar slants (in $\mathrm{g} / \mathrm{L}$ of distilled water: potato 200 , glucose 20 and agar 20). After 5 days of incubation at $28{ }^{\circ} \mathrm{C}$, the spores were harvested, washed with sterilised saline and cultured in several $500-\mathrm{mL}$ flasks $\left(3 \cdot 10^{6}\right.$ spores/ $\mathrm{mL}$ ) containing $1.4 \mathrm{~g}$ of dextrin, $1.05 \mathrm{~g}$ of peptone and 70 $\mathrm{mL}$ of distilled water. The spores were then cultivated in shaking incubator at $150 \mathrm{rpm}$ and $28^{\circ} \mathrm{C}$. After $11 \mathrm{~h}$ of cultivation, a $20 \%$ (by volume) inoculum was transferred into fermentation medium ( $2 \mathrm{~g}$ of dextrin, $1 \mathrm{~g}$ of peptone and $1 \mathrm{~g}$ of soya bean in $50 \mathrm{~mL}$ of distilled water) and fermented at $28^{\circ} \mathrm{C}$ and $150 \mathrm{rpm}$ for $60 \mathrm{~h}$.

The supernatant containing the enzyme was obtained by centrifugation at $4{ }^{\circ} \mathrm{C}$ and $8944 \times g$ for $10 \mathrm{~min}$, and stored at $-20^{\circ} \mathrm{C}$ for purification.

\section{Identification by molecular biology methods}

The DNA of R. microsporus was extracted by a Fungus Genomic DNA Extraction Kit (Beijing Sunbiotech Co. Ltd, Beijing, PR China) according to the manufacturer's instructions. Polymerase chain reaction (PCR) amplifications were achieved using universal primers for ribosomal DNA regions (10). Primers ITS5 (5'-GGAAGTAAAAGTCGTAACAAGG-3') and ITS4 (5'-TCCTCCGCTTATTGATA TGC-3') were used. The following thermocycler protocol was used: 1 cycle at $95^{\circ} \mathrm{C}$ for $3 \mathrm{~min}$, then 35 cycles at $95^{\circ} \mathrm{C}$ for $30 \mathrm{~s}$, at $55^{\circ} \mathrm{C}$ for $30 \mathrm{~s}$ and $72{ }^{\circ} \mathrm{C}$ for $1 \mathrm{~min}$, and 1 cycle at $72{ }^{\circ} \mathrm{C}$ for $7 \mathrm{~min}$. The PCR reaction mixture consisted of 5 $\mu \mathrm{L}$ of $10 \times$ PCR buffer, $1 \mu \mathrm{L}$ of $\mathrm{dNTP}(10 \mathrm{mmol} / \mathrm{L}), 2 \mu \mathrm{L}$ of ITS5 $(10 \mu \mathrm{mol} / \mathrm{L}), 2 \mu \mathrm{L}$ of ITS4 $(10 \mu \mathrm{mol} / \mathrm{L}), 1 \mu \mathrm{L}$ of template DNA, $50 \mu \mathrm{L}$ of double distilled water and $1 \mathrm{U}$ of Taq polymerase. The PCR amplification products were determined by Beijing Liuhe Huada Gene Technology Co., Ltd Beijing, PR China. A homology search using the reference strains registered in DDBJ/EMBL/GenBank was performed by NCBI BLAST (11).

\section{Determination of enzyme concentration and fibrinolytic activity}

Protein (enzyme) concentration was determined by the method of Bradford (12), according to which G-250 dye reagent and bovine serum albumin were used as standards and the absorbance was measured at $595 \mathrm{~nm}$.

Enzyme activity was determined using the fibrin plate method $(13,14)$, with some modifications. The $9-\mathrm{cm}$ Petri dishes contained fibrin plate composed of: $20 \mathrm{mg}$ of blood fibrinogen in $5 \mathrm{~mL}$ of $0.1 \mathrm{M}$ barbital buffer ( $\mathrm{pH}=7.8$ ), $20 \mathrm{U}$ of thrombin solution, and $25 \mathrm{mg}$ of agarose in $5 \mathrm{~mL}$ of medical physiological saline. For the determination of fibrinolytic activity, $10 \mu \mathrm{L}$ of enzyme solution were carefully added onto a fibrin plate and incubated at $37^{\circ} \mathrm{C}$ for $6 \mathrm{~h}$. The activity of fibrinolytic enzyme was estimated by measuring the dimension of the clear zone on the fibrin plate and plotting a calibration curve based on urokinase standard solutions. One unit of urokinase activity was defined as the amount of enzyme that dissolves $1 \mu \mathrm{g}$ of fibrinogen clot per min per $\mathrm{mL}$ at $37^{\circ} \mathrm{C}$.

\section{Enzyme purification}

The enzyme was purified through the following steps: (i) solid ammonium sulphate was added to the supernatant containing the fibrinolytic enzyme to make $30 \%$ saturation. This mixture was left overnight at $4{ }^{\circ} \mathrm{C}$ and then centrifuged at $7000 \times g$ for $30 \mathrm{~min}$ at $4{ }^{\circ} \mathrm{C}$ to remove particle material. Solid ammonium sulphate was added to the supernatant until it reached $65 \%$ saturation and then left overnight at $4{ }^{\circ} \mathrm{C}$. The precipitate was collected by centrifugation at $12700 \times g$ for $30 \mathrm{~min}$ at $4{ }^{\circ} \mathrm{C}$ for further purification; (ii) the crude enzyme precipitate was dissolved in Tris- $\mathrm{HCl}$ buffer $(20 \mathrm{mM}, \mathrm{pH}=7.5)$, desalted with dialysis bag (molecular mass of $8000 \mathrm{Da}$ ) at $4{ }^{\circ} \mathrm{C}$ and concentrated by lyophilisation; (iii) the dialysed sample was loaded onto a DEAE-Sepharose Fast Flow column $(2.5 \mathrm{~cm} \times 20 \mathrm{~cm})$ previously equilibrated with $20 \mathrm{mM}$ Tris- $\mathrm{HCl}$ buffer ( $\mathrm{pH}=7.5)$. After washing with two bed volumes of starting buffer, the elution was performed with a linear gradient of 0-1.0 $\mathrm{M} \mathrm{NaCl}$ at a flow rate of $1 \mathrm{~mL} / \mathrm{min}$ with a constant flow pump (DHL-A, Shanghai Huxi Analysis Instrument Factory, PR China). The fractions were collected by an autocollector (DBS-100, Shanghai Huxi Analysis Instrument Factory) and analysed for fibrinolytic enzyme activity and protein content. The active fractions were pooled and concentrated to $2.0 \mathrm{~mL}$ with PEG-20000 (BioSharp, Anhui, PR China); and (iv) the concentrated sample obtained using DEAE-Sepharose Fast Flow column chromatography (1.0 $\mathrm{mL}, 0.065 \mathrm{mg} / \mathrm{mL}$ ) was applied on a Sephadex G-75 column (1.6 cm $\times 80 \mathrm{~cm}$, Agilent Co., Beijing, PR China), equilibrated with $0.1 \mathrm{M}$ phosphate buffer $(\mathrm{pH}=7.5)$, and then the fibrinolytic enzyme was eluted with the same buffer $(\mathrm{pH}=7.5)$, at a flow rate of $1 \mathrm{~mL}$ per min, with a constant flow pump. The fractions of $5.0 \mathrm{~mL}$ were collected by an autocollector and assayed for fibrinolytic enzyme activity and protein content. The active fractions were pooled, concentrated and analysed for purity by SDS-PAGE (BioDev, Beijing, PR China) and HPLC (GE SuperdexTM Peptide 10/300 GL, $10 \mathrm{~mm} \times 300 \mathrm{~mm}$, GE Healthcare).

\section{Determination of enzyme purity}

Sodium dodecyl sulphate-polyacrylamide gel electrophoresis (SDS-PAGE) was carried out according to the method of Laemmli on $4 \%$ (by mass per volume) polyacrylamide stacking gel and $12 \%$ (by mass per volume) polyacrylamide resolving gel in an electrophoresis cell (DYCE-24DN, Beijing Wode-Life Sciences Instrument Co., Beijing, PR China) with the electrophoresis apparatus (DYY-6B, Beijing Wode-Life Sciences Instrument Co.). Protein bands were visualised by staining with Coomassie brilliant blue R250 (Amresco LLC, Solon, OH, USA) and estimated by comparing with broad range molecular mass standards from 14.4 to $66.2 \mathrm{kDa}$. 
After filtration chromatography $(10 \mu \mathrm{L}, 10 \mathrm{mg} / \mathrm{mL})$, the sample was subjected to HPLC (Agilent Technologies, Palo Alto, CA, USA) using a GE Superdex ${ }^{\circledast}$ Peptide 10/300 GL $(10 \mathrm{~mm} \times 300 \mathrm{~mm})$. The eluent was $50 \mathrm{mmol} / \mathrm{L}$ phosphate buffer with $0.15 \mathrm{~mol} / \mathrm{L} \mathrm{NaCl}$ at a flow rate of $0.5 \mathrm{~mL}$ per min at $30^{\circ} \mathrm{C}$. The purity of the sample was measured by detecting UV absorbance at $214 \mathrm{~nm}$. The fractions of $5.0 \mathrm{~mL}$ were collected by an autocollector and assayed for fibrinolytic enzyme activity.

\section{Characterisation of fibrinolytic enzyme activity}

Effect of artificial intestinal fluid on the fibrinolytic enzyme activity

A volume of $0.5 \mathrm{~mL}$ of fibrinolytic enzyme solution $(0.035 \mathrm{mg} / \mathrm{mL})$ and $1 \mathrm{~mL}$ of artificial intestinal fluid $(6.8 \mathrm{~g}$ of $\mathrm{KH}_{2} \mathrm{PO}_{4}, 5 \mathrm{~g}$ of trypsin and $500 \mathrm{~mL}$ of distilled water, adjusted to $\mathrm{pH}=6.8$ with $0.1 \mathrm{M} \mathrm{NaOH}$ ) was mixed to determine the retaining activity after $1,2,3$ and $4 \mathrm{~h}$ at $37^{\circ} \mathrm{C}$. The enzyme activity was determined as a percentage of the relative activity compared to that of the control, which was $100 \%$.

Effect of $\mathrm{pH}$ on the fibrinolytic enzyme activity and stability

The optimal $\mathrm{pH}$ for the fibrinolytic enzyme $(0.035$ $\mathrm{mg} / \mathrm{mL}$ ) was determined by measuring the enzyme activity within a $\mathrm{pH}$ range of $2.8-11.8$ at $37^{\circ} \mathrm{C}$. The $\mathrm{pH}$ stability of the fibrinolytic enzyme was estimated by measuring the remaining fibrinolytic activity after incubating the enzyme for $24 \mathrm{~h}$ at $37^{\circ} \mathrm{C}$ with different buffers. The residual enzyme activity was then measured at $\mathrm{pH}=7.0$. The following buffer systems were used: $0.02 \mathrm{M}$ disodium phosphate/citric acid buffer ( $\mathrm{pH}=2.8-6.8$ ), $0.02 \mathrm{M}$ barbitone sodium $/ \mathrm{HCl}$ buffer ( $\mathrm{pH}=7.8-8.8$ ), $0.02 \mathrm{M} \mathrm{Na}_{2} \mathrm{CO}_{3} / \mathrm{NaHCO}_{3}$ buffer ( $\mathrm{pH}=9.8-10.8), 0.02 \mathrm{M}$ disodium phosphate/ $\mathrm{NaOH}$ $(\mathrm{pH}=11.8)$ and $0.02 \mathrm{M} \mathrm{KCl} / \mathrm{NaOH}$ buffer $(\mathrm{pH}=12.2)$. The enzyme activity was measured using the fibrin plate method, and expressed as a relative percentage to the maximum activity of $100 \%$.

Effect of temperature on the fibrinolytic enzyme activity and stability

The optimal temperature of the enzyme $(0.035 \mathrm{mg} /$ $\mathrm{mL}$ ) was evaluated by measuring the enzyme activity at different temperatures $\left(25-70{ }^{\circ} \mathrm{C}\right)$ for $16 \mathrm{~h}$. The effect of temperature on the enzyme stability was determined by measuring the residual activity of the enzyme incubated in $50 \mathrm{mM}$ sodium phosphate buffer $(\mathrm{pH}=7.0)$ at temperatures ranging from 25 to $70^{\circ} \mathrm{C}$ for $4 \mathrm{~h}$. The fibrinolytic activity was assessed by the fibrin plate method.
Effect of metal ions on the fibrinolytic enzyme activity

The effect of different metal ions was investigated by using $\mathrm{MgSO}_{4}, \mathrm{CuSO}_{4}, \mathrm{KCl}, \mathrm{CaCl}_{2}, \mathrm{ZnSO}_{4}, \mathrm{MnSO}_{4}, \mathrm{FeSO}_{4}$ and $\mathrm{NaCl}$ solutions. The fibrinolytic enzyme $(0.035 \mathrm{mg} /$ $\mathrm{mL}$ ) was incubated with different metal ion saline solutions $(1$ and $10 \mathrm{mM})$ for $18 \mathrm{~h}$ at $37^{\circ} \mathrm{C}$. The residual activity was measured by the fibrin plate method. The activity of the fibrinolytic enzyme assayed in the absence of metal ions was taken as $100 \%$.

Activation of plasminogen by the fibrinolytic enzyme

The commercially available fibrinogen contains plasminogen which can be activated into plasmin. The plasminogen on the fibrin plate can be deactivated by heating, when it loses its fibrinolytic activity. After the prepared plasminogen-positive fibrin plate was incubated at $85^{\circ} \mathrm{C}$ for $30 \mathrm{~min}$ and cooled to room temperature, plasminogen-free fibrin plate was made. If the fibrinolytic enzyme $(0.035 \mathrm{mg} / \mathrm{mL})$ dissolved much more fibrin on plasminogen-positive fibrin plate than on plasminogen-free fibrin plate, it meant that the activated fibrinolytic enzyme dissolved protein fibre in an indirect way. However, the results on plasminogen-free fibrin plate show that the enzyme degrades fibrin directly. The purified enzyme from R. microsporus and urokinase solution $(10 \mu \mathrm{L})$ was added onto the plasminogen-free and plasminogen-positive fibrin plates in order to determine the nature of fibrin degradation.

\section{Results and Discussion}

\section{Identification of the Rhizopus microsporus}

The strain was identified as Rhizopus microsporus based on an analysis of ITS-5.8S rDNA sequences, which revealed $99 \%$ homology. The strain was deposited in China General Microbiological Culture Collection Center, CGMCC, Beijing, PR China (CGMCC No. 4368).

\section{Purification and confirmation of activity of the enzyme}

The fibrinolytic enzyme from $R$. microsporus var. tuberosus was partially purified as shown in Table 1. After the ammonium sulphate precipitation, a DEAE-Sepharose Fast Flow column and a Sephadex G-75 column chromatography were used to partially purify the enzyme. Two protein peaks were detected. The major fraction with fibrinolytic activity was collected and applied onto the Sephadex G-75 column. Only a minor peak showed fibrinolytic activity (figure not shown).

The purity of the enzyme preparation was measured by SDS-PAGE, which showed one dominant protein band with the molecular mass of about $24.5 \mathrm{kDa}$ (Fig. 1). This is

Table 1. Purification of the extracellular fibrinolytic enzyme from Rhizopus microsporus var. tuberosus

\begin{tabular}{|c|c|c|c|c|c|}
\hline Purification step & $\frac{\gamma(\text { protein })}{\mathrm{mg} / \mathrm{mL}}$ & $\frac{\text { Activity }}{\mathrm{U} / \mathrm{mL}}$ & $\frac{\text { Specific activity }}{\mathrm{U} / \mathrm{mg}}$ & $\frac{\text { Yield }}{\%}$ & $\begin{array}{l}\text { Purification } \\
\text { fold }\end{array}$ \\
\hline Cell-free supernatant & $7.5 \pm 0.8$ & $324.7 \pm 16.2$ & $43.2 \pm 2.2$ & 100 & 1 \\
\hline$\left(\mathrm{NH}_{4}\right)_{2} \mathrm{SO}_{4}$ precipitation & $0.67 \pm 0.07$ & $182.6 \pm 9.1$ & $272.0 \pm 13.6$ & 56.2 & 6.3 \\
\hline DEAE-Sepharose Fast Flow & $0.065 \pm 0.007$ & $68.7 \pm 3.4$ & $1062.2 \pm 23.1$ & 21.2 & 24.6 \\
\hline Sephadex G-75 & $0.035 \pm 0.004$ & $57.6 \pm 2.9$ & $1645.2 \pm 32.9$ & 17.8 & 38.1 \\
\hline
\end{tabular}


lower than that of the enzyme that coagulates the protein in soya bean milk (30.0 kDa) from Bacillus pumilus TYO-67 (15) and higher than that from Rhizopus chinensis 12 (16.6 $\mathrm{kDa}$ (16). In addition, according to the results of HPLC, the fibrinolytic enzyme was partially purified, showing only one major peak (Fig. S1).

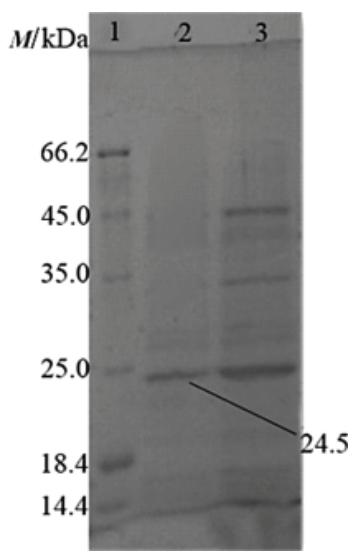

Fig. 1. SDS-PAGE profile of enzyme purification. 1=marker, $2=$ sample after gel filtration chromatography, and $3=$ sample after ion exchange chromatography

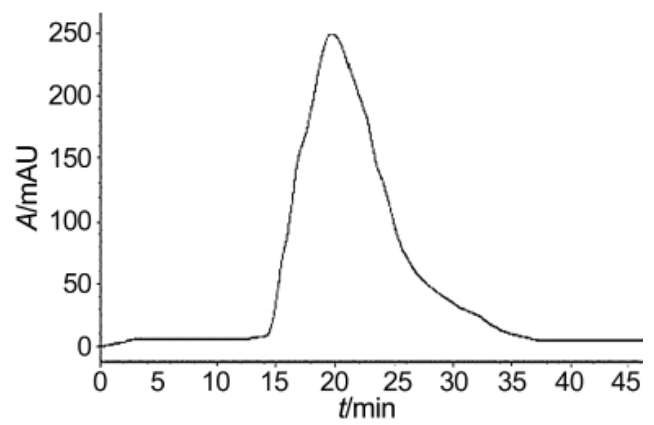

Fig. S1. The purity of the fibrinolytic enzyme determined by HPLC gel-filtration chromatography

After all purification steps, the enzyme was purified 38.1-fold, with a final yield of $17.75 \%$ and the specific ac-

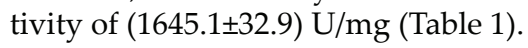

\section{Characterisation of the fibrinolytic enzyme}

The enzyme was stable in the artificial intestinal fluid and retained more than $80 \%$ of its original activity after 4 $\mathrm{h}$ of preincubation (Table 2). It is indicated that the enzyme could be resistant to trypsin in vivo, and could have a potential to be developed as oral drug. Oral administration of the fibrinolytic enzyme nattokinase has been reported to enhance fibrinolytic activity in plasma and the production of endogenous plasminogen activators, such as t-PA (17).

Table 2. Effect of artificial intestinal fluid on the fibrinolytic enzyme

\begin{tabular}{lcccc}
\hline$t$ (preincubation) $/ \mathrm{h}$ & 1 & 2 & 3 & 4 \\
\hline Residual activity/\% & $95.2 \pm 8.6$ & $94.5 \pm 9.7$ & $90.4 \pm 8.4$ & $83.3 \pm 8.7$
\end{tabular}

The $\mathrm{pH}=7.0$ was found to be optimum for the fibrinolytic activity of the enzyme (Fig. 2a). Since the enzyme had a wide range of $\mathrm{pH}$ adaptability, it remained active even when the $\mathrm{pH}$ of the fibrin plate was adjusted to $\mathrm{pH}<$ 3.4 and $>11.2$. The $\mathrm{pH}$ stability of the enzyme was tested in the $\mathrm{pH}$ range of 3.0 to 12.0 by measuring the residual activity after incubation for $24 \mathrm{~h}$ at each $\mathrm{pH}$ (Fig. 2b). The enzyme was stable in the $\mathrm{pH}$ range from 6.0 to 8.0 for $24 \mathrm{~h}$ at $37^{\circ} \mathrm{C}$, which was the optimum temperature for the enzyme activity (Fig. 2c) and the enzyme showed approx.

a)

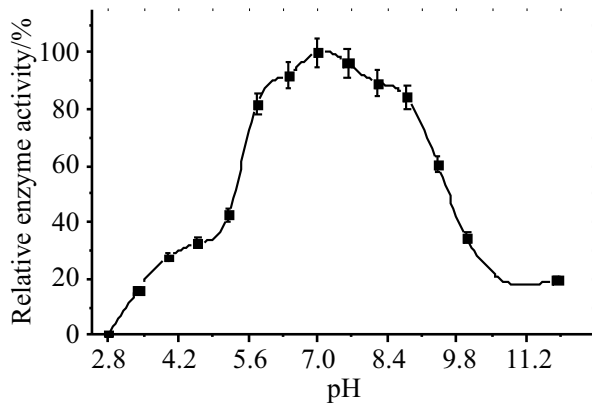

b)

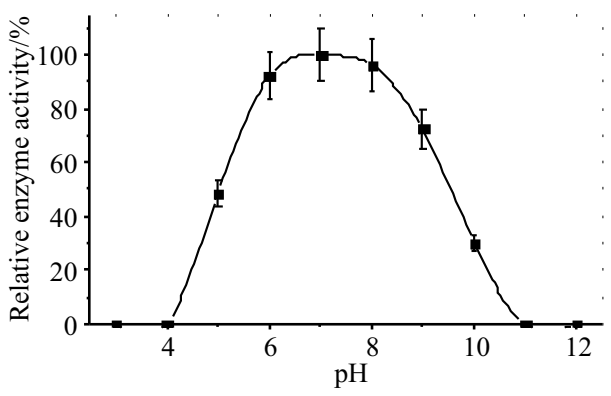

c)

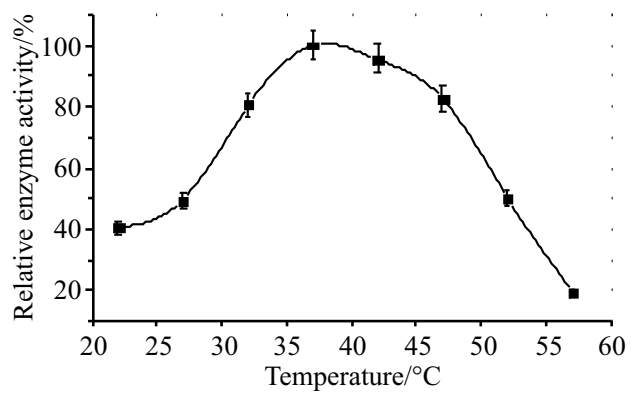

d)

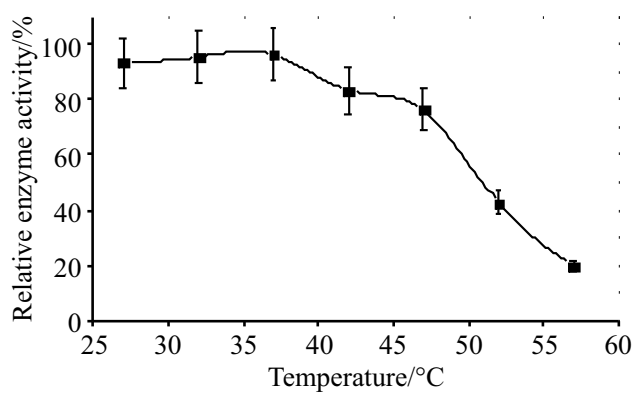

Fig. 2. Characterisation of the influence of $\mathrm{pH}$ and temperature on the enzyme activity and stability: effect of $\mathrm{pH}$ on a) the activity and b) stability ( $24 \mathrm{~h}$ at $\left.37^{\circ} \mathrm{C}\right)$; effect of temperature on c) the activity and $\mathrm{d}$ ) stability $\left(4 \mathrm{~h}\right.$ at $\left.27-57^{\circ} \mathrm{C}\right)$. The values of the activities that correspond to $100 \%$ were: a) 292.23 , b) 286.34 , c) 314.26 and d) $302.58 \mathrm{U} / \mathrm{mL}$ 
$96.1 \%$ residual activity after $4 \mathrm{~h}$ of incubation at $37^{\circ} \mathrm{C}$ (Fig. 2d). The optimum $\mathrm{pH}(7.0)$ and temperature $\left(37^{\circ} \mathrm{C}\right)$, which are very close to physiological conditions, suggest the possibility of clinical applications of the enzyme.

The effect of metal ions showed that $\mathrm{Zn}^{2+}$ and $\mathrm{Cu}^{2+}$ hinder the enzyme activity, whereas $\mathrm{Na}^{+}, \mathrm{Ca}^{2+}, \mathrm{Mn}^{2+}$ and $\mathrm{Mg}^{2+}$ showed obvious stimulation of the enzyme (Fig. 3).

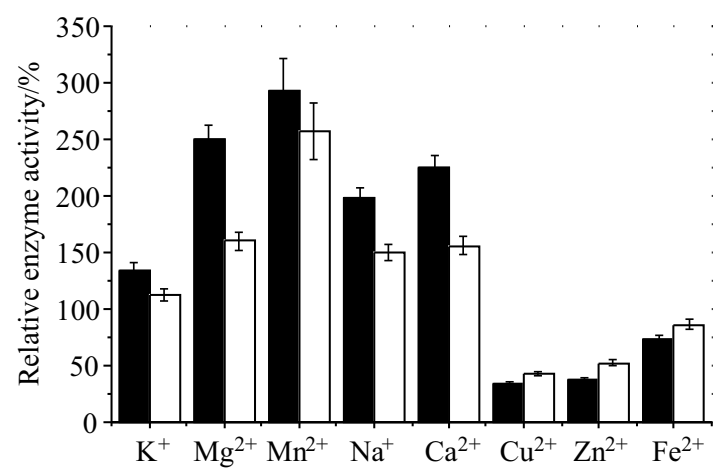

Fig. 3. Effect of metal ions on the activity of the fibrinolytic enzyme. The activity value that corresponds to $100 \%$ was 292.64 $\mathrm{U} / \mathrm{mL}$. Metal salt concentration:-ロ-1 mM, $-\square-10 \mathrm{mM}$

On the plasminogen-positive fibrin plate, the fibrinolytic enzyme formed a clear zone $(18.32 \mathrm{~mm} \times 18.28 \mathrm{~mm})$ which was larger than that $(16.08 \mathrm{~mm} \times 15.28 \mathrm{~mm})$ on the plasminogen-free fibrin plate. This showed that the fibrinolytic enzyme produced by $R$. microsporus var. tuberosus could activate plasminogen into plasmin to degrade fibrin (Fig. 4). The clear zone on the plasminogen-free fibrin plate indicates that the fibrinolytic enzyme from $R$. microsporus var. tuberosus could degrade fibrin directly, in contrast to urokinase.
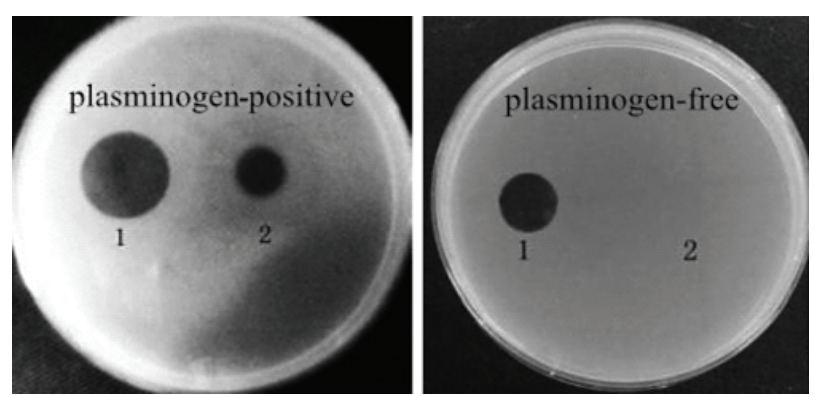

Fig. 4. Activation of plasminogen by the fibrinolytic enzyme. $1=$ fibrinolytic enzyme, and $2=$ urokinase

\section{Conclusions}

The fibrinolytic enzyme from Rhizopus microsporus var. tuberosus was partially purified, and thus purified enzyme had maximum activity at $37^{\circ} \mathrm{C}$ and $\mathrm{pH}=7.0$, and showed stronger resistance to the inhibition by trypsin. It was stable at $37^{\circ} \mathrm{C}$ and retained $96.1 \%$ of its original activity after being incubated for $4 \mathrm{~h}$. The activity of the enzyme is promoted in the presence of $\mathrm{Na}^{+}, \mathrm{Ca}^{2+}, \mathrm{Mg}^{2+}$ and $\mathrm{Mn}^{2+}$, whereas the presence of $\mathrm{Zn}^{2+}$ and $\mathrm{Cu}^{2+}$ partially in- hibits its activity. The enzyme not only degrades fibrin directly, but also activates plasminogen into plasmin to degrade fibrin. The results indicate the potential of the pure enzyme in dissolving blood clot, and the possibility for application in the therapy of thrombosis.

Further research and more clinical trials are needed to verify the safety of the application of fibrinolytic enzyme as an oral thrombolytic agent, detect its potential side effects and study its induction of in vivo lysis of thrombi or its industrialised production.

\section{Acknowledgements}

This work was supported by Tianjin Natural Science Foundation (No. 09ZCKFNC00800), Tianjin, PR China.

\section{References}

1. Mine $\mathrm{Y}$, Wong AHK, Jiang B. Fibrinolytic enzymes in Asian traditional fermented foods. Food Res Int. 2005;38:243-50. http://dx.doi.org/10.1016/j.foodres.2004.04.008

2. Shao RJ. Screening of efficient thrombolytic strains and comparative analysis of methods for detecting thrombolytic activity. Journal of Chongqing Normal University. 2012:1-1 (in Chinese).

3. Liberatore GT, Samson A, Bladin C, Schleuning WD, Medcalf RL. Vampire bat salivary plasminogen activator (desmoteplase): a unique fibrinolytic enzyme that does not promote neurodegeneration. Stroke. 2003;34:537-43. http://dx.doi.org/10.1161/01.STR.0000049764.49162.76

4. Wang F, Wang C, Li M, Gui L, Zhang J, Chang W. Purification, characterization and crystallization of a group of earthworm fibrinolytic enzymes from Eisenia fetida. Biotechnol Lett. 2003;25:1105-09.

http://dx.doi.org/10.1023/A:1024196232252

5. Sun MZ, Liu S, Greenaway FT. Characterization of a fibrinolytic enzyme (ussurenase) from Agkistrodon blomhoffii Ussurensis snake venom: insights into the effects of $\mathrm{Ca}^{2+}$ on function and structure. BBA-Protein Proteom. 2006;1764: 1340-8.

http://dx.doi.org/10.1016/j.bbapap.2006.06.003

6. Han SM, Weaver FA, Comerota AJ, Perler BA, Joing M. Efficacy and safety of alfimeprase in patients with acute peripheral arterial occlusion (PAO). J Vasc Surg. 2010;51: 600-9. http://dx.doi.org/10.1016/j.jvs.2009.08.053

7. Kim W, Choi K, Kim Y, Park H, Choi J, Lee Y, et al. Purification and characterization of a fibrinolytic enzyme produced from Bacillus sp. strain CK 11-4 screened from ChungkookJang. Appl Environ Microb. 1996;62:2482-8.

8. Sumi H, Hamada H, Tsushima H, Mihara H, Muraki H. A novel fibrinolytic enzyme (nattokinase) in the vegetable cheese natto; a typical and popular soybean food in the Japanese diet. Experientia. 1987;43:1110-1.

http://dx.doi.org/10.1007/BF01956052

9. Wang CT, Ji BP, Li B, Nout R, Li PL, Ji H, Chen LF. Purification and characterization of a fibrinolytic enzyme of Bacillus subtilis DC33, isolated from Chinese traditional douchi. J Ind Microbiol Biot. 2006;33:750-8. http://dx.doi.org/10.1007/s10295-006-0111-6

10. White TJ, Bruns T, Lee S, Taylor J. Amplification and direct sequencing of fungal ribosomal RNA genes for phylogenetics. In: Innis MA, Gelfand DH, Sninsky JJ, et al, editors. PCR protocols: a guide to methods and applications. New York, NY, USA: Academic Press 1990. 315-22. 
11. GenBank ${ }^{\circledR}, \mathrm{NCBI}$, Bethesda, MD, USA; http://www.ncbi.nlm. nih.gov/

12. Bradford MM. A rapid and sensitive method for the quantitation of microgram quantities of protein utilizing the principle of protein-dye binding. Analyt Biochem. 1976;72:24854.

13. Astrup T, Mullertz S. The fibrin plate method for estimating fibrinolytic activity. Arch Biochem Biophys. 1952;40:346-51. http://dx.doi.org/ 10.1016/0003-9861(52)90121-5

14. Walton PL. An improved fibrin plate method for the assay of plasminogen activators. Clin Chim Acta. 1966;13:680-4. http://dx.doi.org/10.1016/0009-8981(66)90177-X
15. Takahashi M, Sekine T, Kuba N, Nakamori S, Yasuda M, Takagi $\mathrm{H}$. The production of recombinant APRP, an alkaline protease derived from Bacillus pumilus TYO-67, by in vitro refolding of pro-enzyme fixed on a solid surface. J Biochem. 2004;136:549-56.

http://dx.doi.org/10.1093/jb/mvh158

16. Liu XL, Du LX, Lu FP, Zheng XQ, Xiao J. Purification and characterization of a novel fibrinolytic enzyme from Rhizopus chinensis 12. Appl Microbiol Biot 2005;67:209-14. http://dx.doi.org/10.1007/s00253-004-1846-5

17. Sumi H, Hamada H, Nakanishi K, Hiratani H. Enhancement of the fibrinolytic activity in plasma by oral administration of nattokinase. Acta Haematol-Basel. 1990;84:139-43. 